Chao Guo* and Dennis R. Young

\title{
Editors' Note: Issue 7:1: Introduction to the ARNOVA Fourth Symposium on Public Policy for Nonprofits Special Issue
}

DOI 10.1515/npf-2015-0049

The nonprofit sector is a large and integral part of the public economy of the United States. The sector contributes roughly $\$ 900$ billion to the U.S. economy, accounting for more than $5 \%$ of $\mathrm{GDP}^{1}$. Public charities alone employ more than 11 million workers, representing more than $10 \%$ of employment ${ }^{2}$. Nonprofits play important roles in providing social, health, education, arts and culture, and many other services, represent the identities and interests of numerous constituencies, experiment with social innovations, and underpin the workings of a vibrant civil society and democracy.

The evolution and development of the U.S. nonprofit sector is inextricably tied to public policy. From President Johnson's War on Poverty to Reagan's sweeping tax and budget policies, from Bush Sr.'s vision of "a thousand points of light" in every community to Clinton's welfare reform aiming to "end welfare as we know it”, from Bush Jr.'s Patriot Act and No Child Left Behind Act to Obama's Affordable Care Act, the growth and changes in the sector correspond to major shifts in public policy. In light of the importance of the nonprofit sector and its interdependent relationship with government, it is imperative to understand how public policies at the federal, state, and local levels foster or hinder the capacity of nonprofit organizations to meet the demands of our society, as well as how nonprofits participate in public policy formulation and implementation through lobbying, advocacy, research and other means.

1 Source: The Urban Institute (2014), The Nonprofit Sector in Brief. Available at: http://www.urban. org/sites/default/files/alfresco/publication-pdfs/413277-The-Nonprofit-Sector-in-Brief-.PDF.

2 Source: Bureau of Labor Statistics (2014), Announcing new research data on jobs and pay in the nonprofit sector. Available at: http://beta.bls.gov/labs/blogs/2014/10/17/announcing-newresearch-data-on-jobs-and-pay-in-the-nonprofit-sector.

*Corresponding author: Chao Guo, University of Pennsylvania, Philadelphia, U.S.A., E-mail: chaoguo@sp2.upenn.edu

Dennis R. Young, Georgia State University, Atlanta, U.S.A., E-mail: dennisryoung@gsu.edu 
It was in this context that ARNOVA hosted its Symposium on Public Policy for Nonprofits in Washington, D.C. on May 13, 2015, with the generous support of the Kresge Foundation. A diverse group of more than thirty outstanding researchers, nonprofit professionals, and policymakers from throughout the U.S. participated. This symposium was the fourth in a series of policy-related convenings hosted by ARNOVA. The first such symposium took place in Baltimore, Maryland in October 2010, with the support and encouragement of the Kresge Foundation, Charles Stewart Mott Foundation, and Bill and Melinda Gates Foundation. That symposium was focused on "mapping" the state of research on public policy related to nonprofit organizations and identifying cutting-edge issues for further conversations. In June of the following year, ARNOVA held its second symposium in Washington, D.C., on the theme of nonprofit finance and public policy. Then in November 2013, ARNOVA convened its third symposium in Hartford, Connecticut to discuss the impact of state and local regulations on nonprofits.

Common to all these symposia is ARNOVA's targeted effort to bring together diversified groups of participants including researchers, nonprofit practitioners, and policy makers with different professional and ideological backgrounds. Unlike its predecessors, this latest symposium was not structured around a single theme but rather open to all policy issues emerging in the nonprofit sector that were deemed important by researchers. In its Call for Proposals, ARNOVA invited scholars and practitioners to submit proposals based on their own policy-relevant research. Given time and space limitations, only seven policy briefs out of more than a dozen excellent proposals were selected for presentation at the symposium; in addition, four other proposals were identified for prospective publication in this issue.

At the symposium itself, the seven selected presentations were each critiqued by two discussants and served as the focus for general discussion by symposium participants. After the symposium the authors revised their papers in response to the feedback they received at the symposium. In addition, the four selected briefs not presented were reviewed through this journal's regular review process and three of them subsequently revised for publication. Altogether, we publish in this issue the ten accepted briefs, plus a detailed commentary provided by the discussant of one of these briefs.

Three major themes emerged from these policy briefs: laws and regulations toward nonprofit organizations; public policy for the delivery of human services; and representation and participation in democratic governance (see Table 1).

These three themes are consistent with prior research on the interaction of nonprofits and public policy. Lowry (1995), for example, identified five categories of interaction: service delivery and program implementation; policy advocacy; public policy toward nonprofits; public/private partnerships; and the private 
Table 1: Major themes among the articles in this issue.

\begin{tabular}{ll}
\hline Major themes & Articles in this issue (in order of presentation) \\
\hline Laws and regulations & $\begin{array}{l}\text { The recent trend among local governments in favor of "PILOTs" } \\
\text { (payments in lieu of taxes) and "SILOTs" (services in lieu of taxes) } \\
\text { (Kirsten Gronbjerg); } \\
\text { Reexamination of humanitarian aid sector policies on Islamic } \\
\text { charities (Sabithulla Khan); } \\
\text { Legal protections for volunteers and volunteer management programs } \\
\text { (Joseph Mead); } \\
\text { Emerging structures of government-nonprofit collaborative relations } \\
\text { (John Casey); } \\
\text { Rebust measures for evaluating nonprofit organizations (Katherine } \\
\text { Cooper and Michelle Shumate); } \\
\text { The impact of public policies on the founding values of the nonprofit } \\
\text { sector (David Hammack with commentary by John Tyler); } \\
\text { Major trends affecting public policy for human services (Steve Smith } \\
\text { and Susan Phillips) } \\
\text { Participatory processes (e.g., task forces, advisory boards, and } \\
\text { citizen councils, etc.) by which nonprofit organizations legitimately } \\
\text { represent communities (Jennifer Mosley) }\end{array}$ \\
\hline
\end{tabular}

production of public goods. Smith and Gronbjerg (2006) identified three dimensions where nonprofits meet public policy: the legal framework under which nonprofits operate; the role they play in the delivery of services; and the efforts they make to influence government's agenda and affect policy change. From an economics perspective, Young (2000) conceptualized nonprofit-government relations as supplementary, complementary, or adversarial. That is, nonprofits may work independently as supplements to government, serve as complements to government in a partnership relationship, or engage in an adversarial relationship of mutual accountability with government. The three themes evidenced in the collection of papers published here build on this literature.

However, the briefs published here are not evenly distributed among the three themes. As shown in Table 1, scholarly interest in public policy for human services dominated this symposium, generating four policy briefs. Laws and regulations toward nonprofits also attracted significant scholarly attention, generating three policy briefs. By contrast, relatively less attention was paid to the political role of nonprofit organizations, with only one brief reflecting the theme of "representation and participation". Emphasis areas aside, it is worth noting that these briefs address interactions of nonprofits and public policy across 
federal, state, and local levels. Taken together, the briefs, as summarized in the table, identify and analyze a number of critical issues and ideas that we believe merit careful attention and further investigation by researchers and policymakers. In addition, the relative lack of attention to the political role of nonprofits and to nonprofit activity outside of the human services, may suggest future opportunities for researchers to contribute to policy debates over the role of nonprofits in U.S. society in heretofore relatively neglected areas.

The success of the symposium and this special issue is the result of the efforts of many individuals. In particular, we thank the members of the Symposium Planning Committee who helped design the Symposium program, reviewed all the proposals, and actively participated in the discussions at the Symposium:

Alan Abramson, George Mason University

Elizabeth Boris, Urban Institute

Hector Cordero-Guzman, City University of New York, Baruch College

Tim Delaney, Council of Nonprofits

Erica Greeley, Independent Sector

Kilolo Kijakazi, Urban Institute

Leslie Lenkowsky, Indiana University

Cindy Lott, Columbia University

Francie Ostrower, University of Texas at Austin

We also thank Alan Abramson (President of ARNOVA), Shariq Siddiqui (Executive Director of ARNOVA), and Fatima Hussain (ARNOVA Special Projects Coordinator), for their support and assistance with planning and logistics. Thanks also go to Rick Cohen (The Nonprofit Quarterly), Lewis Faulk (American University), and Mandi Stewart (Urban Institute) for taking detailed notes at the symposium. Our special appreciation goes to the Urban Institute for hosting the symposium under the leadership of Elizabeth Boris and her staff. Finally, in addition to our authors we would like to acknowledge the contributions of discussants of the symposium papers, including Allison Grayson, Bill Schambra, Catherine Herrold, Elizabeth Boris, Irv Katz, Jasmine McGinnis Johnson, John Tyler, Shirley Sagawa and Tim Delaney.

We trust that readers will find these policy briefs compelling and relevant to their policy, practice and research interests. They cover a wide range of policyrelated topics and we believe that each of them is interesting, unique, and powerful in its own special way. Collectively, these briefs add richness and nuance to our understanding of the manifold complex public policy issues, practices and processes relevant to nonprofit organizations. It is our hope that 
these briefs will continue to stimulate a spirited conversation and inspire further policy-research efforts down the road.

\section{References}

Lowry, R. C. 1995. “Nonprofit Organizations and Public Policy." Review of Policy Research 14 (1-2):107-16.

Smith, S. R., and K. A. Gronbjerg. 2006. "Scope and Theory of Government-Nonprofit Relations." In The Nonprofit Sector: A Research Handbook, edited by W. W. Powell and R. Steinberg, 221-242. New Haven \& London: Yale University Press.

Young, D. R. 2000. "Alternative Models of Government-Nonprofit Sector Relations: Theoretical and International Perspectives." Nonprofit and Voluntary Sector Quarterly 29 (1):149-72. 